\title{
AMADÍS DE GAULA REIVINDICADO POR FELICIANO DE SILVA
}

Amadís de Gaula fue y es el personaje más renombrado de los libros de caballerías españoles del siglo xvi. En siglos posteriores se lo recordó casi exclusivamente por su papel en los cuatro libros de Amadís de Gaula, la refundición y continuación del Amadís primitivo de Garci Rodríguez de Montalvo cuya primera edición conservada es la de 15081. Pero los españoles aficionados a los libros de caballerías podían disfrutar de otras aventuras del paladín en una o varias de las ocho secuelas del Amadís de Rodríguez de Montalvo. El papel del gran héroe decayó en el cuarto libro de Amadís de Gaula de Montalvo y en algunas de sus primeras secuelas, pero recuperó el primer plano junto a sus descendientes en los cinco libros de la serie que escribió Feliciano de Silva (¿1491?-1552)²: el séptimo, Lisuarte de

${ }^{1}$ Rodríguez De Montalvo casi seguramente acabó y probablemente publicó su versión del Amadís antes de 1500 (Amadís de Gaula y Las sergas de Esplandián. Libros de caballerías, ed. P. de Gayangos, Madrid, 1857, en adelante, Sergas). Sobre la fecha del Amadís de Gaula de Montalvo véase el artículo de Rafael Ramos Nogales, "Para la fecha de Amadís de Gaula: «Esta sancta guerra que contra los infieles començada tienen»", BRAE, 74 (1994), 503-521 y el primer capítulo de la tesis doctoral de Emilio Sales Dasí, La figura del caballero en las "Sergas de Esplandián", Universidad de Valencia, 1994.

${ }^{2}$ Información sobre algunos aspectos de los libros de caballerías de Feliciano de Silva se encuentra en mis Feliciano de Silva y los antecedentes de la novela pastoril en sus libros de caballerías, Estudios de Hispanófila, Chapel Hill, 1976 y "Feliciano de Silva and his romances of chivalry in Don Quijote", Inti, 1978, núm. 7, 28-34. Véanse, también, Francisco Curto Herrero, Estructura de los libros de caballerías en el siglo XVI, Fundación Juan March, Madrid, 1976; D. Eisenberg, Romances of chivalry in the Spanish Golden Age, J. de la Cuesta, Newark, 1982, esp. pp. 75-85 y A study of Don Quixote, J. de la Cuesta, Newark, 1987, passim (véase su índice); Alison Dale TAufer, From amazon queen to female knight: The development of the woman warrior in the "Amadis" cycle, tesis, University of California, Los Angeles, 1988 y "The only good amazon is a 
Grecia ${ }^{3}$; el noveno, Amadís de Grecia ${ }^{4}$; el décimo, Florisel de Niquea (primera y segunda partes en un tomo) ${ }^{5}$; el decimoprimero, tercera parte de Florisel de Niquea, mejor conocido como la primera parte de Rogel de Grecia ; y el decimotercero, cuarta parte de Florisel de Niquea, en dos tomos ${ }^{7}$. Eisenberg cataloga veintinueve

converted amazon: The woman warrior and christianity in the Amadis cycle", Playing with gender: A renaissance pursuit, eds. J. R. Brink, M. C. Horowitz, \& A. P. Coudert, Urbana-Chicago, 1991, pp. 35-51; y M. C. DANiEls, "Feliciano de Silva: A sixteenth-century reader-writer of romance", Creation and recreation: Experiments in literary form in Early Modern Spain. Studies in Honor of Stephen Gilman, eds. R. E. Surtz \& N. Weinerth, J. de la Cuesta, Newark, 1983, pp. 77-88 y The function of humor in the Spanish romances of chivalry, Garland, New York-London, 1992, sobre todo el último, que abarca mucho más de lo indicado por el título, y que hasta ahora es el estudio más extenso sobre las obras de Silva. Emilio Sales Dasí ha publicado un estudio sobre el Lisuarte de Grecia, "Feliciano de Silva y la tradición amadisiana en el Lisuarte de Grecia", Incipit, 18 (1998), y otro que incluye comentarios sobre los Rogeles, "Las Sergas de Esplandián y las continuaciones del Amadís (Florisandos y Rogeles)", Voz y Letra, 7 (1996), 131-156.

3 Lisuarte de Grecia. Libro séptimo de Amadís..., Alfonso López, Lisboa, 1587 [1514]. En adelante, cito por título abreviado (Lisuarte) e indico número de la división (si la hay) y de capítulo.

4 Amadís de Grecia. El noveno libro de Amadís de Gaula..., Juan Cromberger, Sevilla, 1542 [1530] (AGrecia).

${ }^{5}$ Florisel de Niquea. La corónica de..., Marcos Borges, Lisboa, 1566 [1532] (Florisel I y II).

${ }^{6}$ Florisel de Niquea. Parte tercera de la corónica del..., Juan Cromberger, Sevilla, 1542 [1535] (Rogel I).

${ }^{7}$ Florisel de Niquea. La primera parte de la quarta de..., Andrea de Portonaris, Salamanca, 1551 (Rogel II.1), y Florisel de Niquea. Segundo libro de la quarta parte..., Pierres de la Floresta, Zaragoza, 1568 [1551] (Rogel II.2). Información sobre ediciones, ubicaciones de muchas ediciones del siglo XVI y estudios sobre los libros de caballerías comentados en este ensayo, en bibliografía indispensable de D. EISENBERG, Castilian romances of chivalry in the sixteenth century: A bibliography, Grant \& Cutler, London, 1979, cuya segunda ed. revisada y aumentada está en prensa. El octavo libro (1526) no es de Silva sino de Juan Díaz, quien nombró el suyo Lisuarte de Grecia sin tomar en cuenta el de Silva. El libro duodécimo de la serie es Silves de la Selva (1546), de Pedro de Luján, quien sí rindió algún tributo a Feliciano de Silva en su prólogo, pero Silva lo criticó acerbamente al final de Rogel II.2 (véase CRAVENS, op. cit., p. 34, n. 43). Silva no es consistente en sus libros en cuanto a la división en partes. Su Lisuarte es un libro breve (113 ff.) sin divisiones interiores. AGrecia y Florisel son largos (más de $200 \mathrm{ff}$.), dividido cada uno en dos partes. En éstos la numeración de los capítulos comienza de nuevo al principio de la segunda parte. Rogel I también es voluminoso pero no está dividido en partes; Rogel II está dividido en dos partes, cada una publicada en su tomo, con nueva numeración de capítulos y folios en el segundo. En los títu- 
ediciones de estos libros de Feliciano de Silva ${ }^{8}$ en el siglo XvI, mismas que tuvieron el Amadís y las Sergas de Esplandián de Montalvo $^{9}$; así pues, la familiaridad de los lectores del siglo xvi con el personaje Amadís, no se debe únicamente a los libros de Montalvo.

Cervantes era uno de los lectores de las continuaciones escritas por Silva; se encuentran en el Quijote $^{10}$ datos concretos y alusiones a casi todos esos libros ${ }^{11}$. Si el hidalgo creía que a su

los completos de Rogel I y Rogel II se nombra primero a Florisel de Niquea, pero luego también a su hijo, Rogel de Grecia, personaje principal de los dos libros, esta es la razón por la que muchos críticos posteriores a Cervantes han preferido Rogel como título abreviado - y también porque Cervantes los llamó "Rugel' en la Primera parte del Quijote (cap. 1; véase Cravens, art. cit., pp. 28 y 30). La mayoría de los bibliógrafos de libros de caballerías y críticos de los libros de Silva suelen señalar Rogel II como la segunda mitad de Rogel I; esto es inexacto. Rogel II fue publicado en 1551, dieciséis años después de la fecha de la primera ed. de Rogel I. Además, en Rogel II se enfatizan características apenas dibujadas en sus predecesores; por ejemplo, los largos episodios pastoriles en los que se elaboran representaciones teatrales en verso. Aunque es cierto que Rogel II es una continuación de Rogel I, cada una de las secuelas de la serie de Amadís continúa una anterior (no siempre la inmediatamente anterior), y a cada una le toca un número en la serie. Por esto y por otras razones, que no aduzco ahora, Rogel II debe ser designado el decimotercer libro de la serie de Amadís.

${ }^{8}$ D. Eisenberg, Romances of chivalry in the Spanish Golden Age, pp. 101-104. El Lisuarte de Silva tuvo diez ediciones entre 1514 y 1587; el AGrecia, siete, entre 1530 y 1596; Florisel, siete, entre 1532 y 1588; Rogel I, cuatro, entre 1535 y 1551 más otra de fecha desconocida; y Rogel II, dos, una en 1551, otra en 1568 (D. EISENBerg, Castilian romances of chivalry in the sixteenth century: A bibliography, pp. 45-51). Un breve informe bibliográfico de JAVIER GUIJARRO ("Bibliografía selecta y tentadora de la literatura caballeresca", Íns, 1995, núms. 584/585, 23-25) advierte la existencia de ediciones críticas de algunos de los libros de caballerías de Silva como tesinas o tesis doctorales: de $\mathrm{Li}$ suarte, preparada ya en 1992 por Carmen Laspuertas Sarvisé; de AGrecia que la investigadora tenía en preparación y de la tercera parte de Florisel de Niquea (Rogel I) que Javier Martín Lalanda tenía en curso. Una "página” en la malla internacional del Ministerio de Educación y Cultura, Secretaría de Estado de Cultura de España (www.mcu.es), cataloga, sin los nombres de sus autores, tesis doctorales que son ediciones del Onceno de Amadís... (Rogel I) y de Florisel de Niquea. La primera parte de la quarta... (Rogel I.1).

${ }^{9}$ El ingenioso hidalgo Don Quijote de la Mancha, ed. L. A. Murillo, Castalia, Madrid, 1985, 3 ts.

${ }^{10}$ D. EISENBERG, Castilian romances of chivalry in the sixteenth century: A bibliography, pp. 28-31 y 43.

11 Véanse S. P. Cravens, art. cit.; D. Eisenberg, Romances of chivalry in the Spanish Golden Age, pp. 131-145; M. C. Daniels, op. cit., caps. 1 y 6-8 y Sales DASÍ, "Feliciano de Silva y la tradición amadisiana en el Lisuarte de Grecia", n. 4. 
edad podía emprender las aventuras en que se había embebido en sus lecturas quizá se debía a que algunos de sus modelos eran también de edad avanzada. Eduardo Urbina opina que Bravor el Brun, el caballero anciano de Tristán de Leonís, podría ser precursor del personaje cervantino ${ }^{12}$, pero no sería descabellado suponer que el Amadís anciano de Silva haya influido también: a poco de empezar la novela, dice Cervantes que el hidalgo llevó a su casa cuantos libros de caballerías pudo comprar, "y de todos, ningunos le parecían tan bien como los que compuso el famoso Feliciano de Silva, porque la claridad de su prosa y aquellas intrincadas razones suyas le parecían de perlas".

Me interesa aquí examinar el papel que Amadís de Gaula desempeñó en las continuaciones, y especialmente la actuación multifacética que tiene en los libros de Feliciano de Silva. Por su relativa importancia o por su singularidad, presento algunos temas con cierto detalle. Por la importancia de la relación entre los libros de caballerías y el Quijote, el propósito secundario es señalar algunas coincidencias entre la obra de Silva y la de Cervantes sin insistir en influencias específicas, ya que la mayoría de los motivos son lugar común en las novelas de caballerías.

A la inversa de Feliciano de Silva, Montalvo no trata muy bien al héroe, sobre todo en el cuarto libro que, por ser obra original, es la primera continuación a su refundición del Amadís primitivo. Al final de ese cuarto libro Amadís lee en voz alta a unos familiares y amigos una carta de Urganda la Desconocida. La maga, que en tantas ocasiones lo había favorecido, ahora lo amonesta a dejar sus aventuras caballerescas y prepararse para las arduas tareas que, como rey que será, le esperan. Urganda pronostica que las proezas de Esplandián eclipsarán las de su padre, porque las pondrá al servicio de la religión, no por la vanagloria y el amor. La carta de Urganda cierra una serie de situaciones del tercero y cuarto libros que rebajan aspectos de la caballería de tipo artúrico en general y a Amadís en particular ${ }^{13}$.

12 "El caballero anciano en Tristán de Leonís y Don Quijote, caballero cincuentón”, NRFH, 29 (1980), 164-172. Recientemente VICENC BELTRÁN ha reafirmado la creencia de que el Tristán ejerció un "poderoso influjo" sobre el Quijote ("Itinerario de los Tristanes", Voz y Letra, 7, 1996, p. 43), y se apoya en el estudio de M. LuzDivina Cuesta sobre las novelas de Tristán: Aventuras amorosas y caballerescas en las novelas de Tristán, Universidad, León, 1994, pp. 219-231.

13 Sobre los aspectos anti-amadisianos en el Amadís de Montalvo consúltense los comentarios de EdWIN B. PLACE, “¿Montalvo autor o refundidor de 
Montalvo continuó en ese tono en las Sergas de Esplandián, $c a .1510^{14}$. En el episodio más notorio de esta tendencia, Amadís, motivado por la envidia poco digna de él, oculta su identidad y desafía a Esplandián a un combate singular. Contra su voluntad, Esplandián lucha con el desconocido y lo vence, dejándolo al borde de la muerte (Sergas 28-29). Es probable que Montalvo haya visto esta derrota menos severa que la muerte que Amadís efectivamente sufrió a manos de su hijo en una versión primitiva ${ }^{15}$. Pero para los lectores aficionados de Amadís la derrota de su adorado héroe frente a no importa qué contrincante habría parecido una indignación bochornosa.

Los escasos episodios en los que participa Amadís en las Sergas no sirven para restaurar su lustre. Ni siquiera sus pasadas

Amadís IV y V?”, Homenaje a Rodríguez-Moñino, Castalia, Madrid, 1966, t. 2, pp. 77-80; José Amezcua, "La oposición de Montalvo al mundo de Amadís", NRFH, 21 (1972), 320-337, esp. pp. 326-327; José Manuel Cacho Blecua, Amadis: heroísmo mítico cortesano, Cupsa, Madrid, 1979, pp. 327-346; JuAN BAUtista Avalle-Arce, "El Amadís primitivo", CH(6), pp. 79-82 y Amadís de Gaula. El primitivo y el de Montalvo, F.C.E., México, 1990, passim, esp. pp. 369-376; y SAles Dasí, "Las Sergas de Esplandián y las continuaciones del Amadís (Florisandos y Rogeles)”, p. 135.

${ }^{14}$ La actitud negativa hacia Amadís en las Sergas ha sido comentada por muchos estudiosos en los últimos cincuenta años, entre ellos, SAMUEL GiLI GAYA ("Las Sergas de Esplandián como crítica de la caballería bretona", BBMP, 23, 1947, 103-111); María Rosa Lida de Malkiel ("El desenlace del Amadís primitivo", $R P h, 6,1952-53,283-289)$; E. B. Place ("Montalvo's outrageous recantation", HR, 37, 1969, 192-198); J. AMEzcuA (art. cit.); Eloy R. GONZÁlez \& JENNIFER T. RoberTs ("Montalvo's recantation, revisited", $B H S$, 55, 1978, 203-210); James FogelQuist (El Amadís y el género de la historia fingi$d a$, J. Porrúa Turanzas, Madrid, 1982, pp. 137-138, 181 y 186-187); ANTHONY VAN BEYSTERVELDT ("La transformación de la misión del caballero andante en el Esplandián y sus repercusiones en la concepción del amor cortés", ZRPh, 97, 1981, 352-369); J. Richard ANDrews ("The plot against Amadís", Hispanic studies in honor of Joseph H. Silverman, ed. J. V. Ricapito, J. de la Cuesta, Newark, 1988, pp. 15-21); J. B. Avalle-Arce ("La aventura caballeresca de Garci Rodríguez de Montalvo", Studies in honor of Bruce W. Wardropper, eds. D. Fox, H. Sieber \& R. Ter Horst, J. de la Cuesta, Newark, 1989, pp. 21-32 y op. cit., passim, esp. pp. 388-389); M. C. Daniels (op. cit., pp. 73-80) y Sales DAsí (en varios, esp. en "Las Sergas de Esplandián: ¿una ficción ejemplar?", Historias y ficciones: Coloquio sobre la literatura del siglo XV, eds. R. Beltrán, J. L. Canet y J. L. Sirera, Universidad, Valencia, 1994, pp. 83-92). Sales Dasí ha analizado una miríada de aspectos del Esplandián en su tesis doctoral ( $\mathrm{La}$ figura del caballero en las "Sergas de Esplandián") y en artículos relacionados.

${ }^{15}$ LidA DE MALKiEL (art. cit.) comprobó la existencia y naturaleza de ese episodio. Véanse también CACHO Blecua (op. cit., pp. 371-372 y 389-400) y Avalle-Arce ("El Amadís primitivo" y op. cit., passim, esp. pp. 119-124). 
glorias escapan del ojo crítico de Montalvo; quien las desvirtúa con frecuentes comentarios moralizantes en contra de la caballería vanagloriosa, ejemplificada por Amadís, cuyo deseo de fama y amor profano hacia Oriana habían sido los móviles de sus famosas proezas. El narrador se mete como personaje en un episodio soñado o encantado y declara a la sabia Urganda su opinión que el mejor caballero de su generación no había sido Amadís sino su medio hermano Florestán y que la princesa más hermosa no había sido Oriana sino Briolanja (Sergas 99). La perspectiva crítica de Montalvo hacia Amadís y sus venturas pasó al sexto libro del ciclo, la crónica de Florisando (1510) de Ruy Páez de Ribera; Amadís aparece aquí como un monarca agobiado por problemas políticos y militares. Su pasado glorioso se recuerda como un modelo que los mozos deben superar con hazañas más calificadas y cristianas. Aun así Páez de Ribera hace de Amadís el "objeto de un renovado proceso de recristianización" 16 .

Lisuarte de Grecia (1526) obra del bachiller en cánones Juan Díaz trata principalmente de los hechos de este nieto de Amadís, hijo de Esplandián. En Lisuarte, continuación de las Sergas, aunque se incorporan ciertos elementos de Florisando, Amadís decae cada vez más hasta morir de penas y vejez. Juan Díaz intentó rematar la campaña en contra de Amadís, concediéndole tan sólo un entierro suntuoso ${ }^{17}$.

El envilecimiento de un héroe tan amado como Amadís no pudo ser del gusto de sus muchos aficionados. Uno de los más ávidos era Feliciano de Silva. Doce años antes de que apareciera

16 SAles Dasí, "El Florisando: libro «sexto» en la familia del Amadís", Literatura de caballerías y orígenes de la novela, ed. R. Beltrán Vallador, Universidad, Valencia, 1998, p. 151. Este autor ha analizado ampliamente el Florisando en un estudio reciente: "Las Sergas de Esplandián y las continuaciones del Amadis (Florisandos y Rogeles)", pp. 141-147. Anteriormente, Maxime Chevalier ("Le roman de chevalerie morigéné", BHi, 40, 1958, 441-449); E. B. Place ("Montalvo's outrageous recantation", pp. 196-198) y J. A. WHITENACK ("Conversion to christianity in the Spanish romance of chivalry, 1490-1524", JHPh, 13, 1988, 28-31), habían comentado aspectos del Florisando resumidos en este ensayo.

17 Pascual de Gayangos reprodujo un resumen del octavo libro en su Discurso preliminar (Libros de caballerías con un discurso preliminar y un catálogo razonado, Rivadeneyra, Madrid, 1857, pp. xxix-xxx); otro resumen y algunos comentarios más son de JOAN GIVANEL I MAS ("Una papereta crítico-bibliográfica referent al Octavo libro de Amadís de Gaula", Homenaje ofrecido a Menéndez Pidal, Hernando, Madrid, 1925, pp. 389-401). El Lisuarte de Díaz fue el único libro de la serie de los Amadises que no fue reeditado ni una sola vez, lo que sugiere que tuvo poca recepción. 
el Lisuarte del bachiller Díaz, el joven Silva había publicado un Lisuarte de Grecia (1514), séptimo libro del ciclo. Como el de Díaz, el Lisuarte de Silva es una continuación a las Sergas, cuya trama imita mucho, pero sin incluir las digresiones moralizantes.

Hacia el final de su Lisuarte Silva inició la reivindicación del héroe disminuido por Montalvo y Páez de Ribera en una aventura que parece recordar el combate entre Amadís y Esplandián en las Sergas ${ }^{18}$. Dos caballeros desconocidos vestidos de armas negras defienden el paso de un puente. Vencen a cincuenta caballeros de dos en dos. Entonces Lisuarte y Perión, los héroes de esta narración, entran en combate con los caballeros de negro. Después de feroz combate, los cuatro ya malheridos, el mago Alquife los envuelve en una nube negra para interrumpir la pelea y revelar que los defensores del puente son Amadís y Esplandián, quienes han tramado la aventura para reafirmar su bondad caballeresca en respuesta a la fama de Perión, hijo de Amadís y hermano de Esplandián, y Lisuarte, hijo de Esplandián. Varios personajes comentan con asombro la ligereza con que Amadís y Esplandián han expuesto a tanto riesgo sus vidas y las de sus hijos. Pero Urganda los regaña más con humor que con severidad: "Vosotros, señores, que avéis de tener pacíficos vuestros reynos, andáis a saltear caminos"; el maltratado Amadís responde: "Buena señora, si a todos los salteadores les fuessen tan bien castigados sus saltos, pocos avría por el mundo" ( $\mathrm{Li}$ suarte 50). Es de suponer que Silva escribió este episodio para reparar en parte el desprestigio sufrido por Amadís en su derrota en las Sergas. En Lisuarte se reafirma la destreza de Amadís con las armas, su dignidad queda apenas maltratada, y sobre todo, se encuentra nuevamente emparejado con Esplandián. Pero Silva no paró ahí el proyecto de reivindicar a su héroe.

Al parecer, la victoria de Esplandián sobre Amadís en las Sergas siguió molestando a Silva, porque volvió al tema hacia el final de su Amadís de Grecia (1530, noveno libro de la serie), continuación de su Lisuarte. Esta vez Silva procuró rectificar de manera contundente el rebajamiento que Amadís de Gaula había recibido a manos de Montalvo, y de Páez de Ribera y Díaz. En el episodio en cuestión Esplandián se ve forzado a matar en defensa

18 SALES DASí ha resumido este episodio y comentado aspectos significativos en su estudio del Lisuarte de Silva ("Feliciano de Silva y la tradición amadisiana en el Lisuarte de Grecia"). Sales señala la "reivindicación de las virtudes caballerescas y amorosas" en el Lisuarte de Silva, esp. en el segundo bloque argumental del libro (pp. 37-38, cito por la versión mecanografiada). 
propia a un caballero soberbio que lo ataca por un malentendido. Una sirvienta del muerto acude llorando a otro caballero armado que halla a poca distancia, le cuenta una versión falsa de lo ocurrido y le pide venganza. El caballero desconocido, así engañado, embiste a Esplandián, cuyas armas también ocultan su identidad. Después de una lucha colosal el desconocido vence a Esplandián con un golpe que lo deja inconsciente. Familiares de Esplandián que habían presenciado la batalla, le quitan el yelmo, lo reconocen, e inmediatamente después ocurre lo mismo con quien lo ha vencido. Mediante su cronista ficticio, el mago Alqui$\mathrm{fe}$, Silva se dirige a sus lectores para revelar la identidad del caballero vencedor y para realzar su imagen sobre la de Esplandián:

sabed que era el esforçado rey Amadís aquel que jamás ninguno ygualó a su bondad sino fue aquel que de su nombre como de sus obras fue tan semejable (ésta es una alusión a Amadís de Grecia). Porque quiero que sepays que hasta aquí jamás aquestos cavalleros padre \& hijo se combatieron. $\mathrm{Ni}$ aun entonces se combatieran sino por la estraña forma de su venida no se conosciendo. Porque el coronista de [E] splandián en sus sergas por dar la mayor gloria que jamás alcançó cavallero a este emperador lo quiso hazer vencedor de su padre el rey Amadís, el qual de nadie jamás fue vencido, y él a todos quantos con él se provaron sí. Por do parece assí por su bondad como por saber aquella batalla ser fabulosa, porque no cabía en razón que siendo su padre le salteasse al camino conociendo lo, no ya que hiziera en su bondad ser tan presto vencido como agora claro muestra la experiencia desta batalla la verdad (AGrecia II: 128).

El contraataque frente a los detractores de Amadís se recrudece: en el siguiente capítulo, Silva, acalorado quizás por la refutación que acaba de dirigir a Montalvo, desacredita también al Florisando de Páez de Ribera y el Lisuarte del bachiller Díaz, alegando que la verdadera continuación de las Sergas es el $\mathrm{Li}$ suarte del sabio Alquife (entiéndase el suyo, AGrecia II: 129). Es algo irónico que Silva haya copiado de Montalvo esta combinación de un episodio que corrige y sustituye otro de un libro anterior con refutaciones del narrador para reclamar veracidad histórica. Esta pretensión de historicidad es esencial en los libros de caballerías ${ }^{19}$. Es el mismo recurso que Cervantes con-

19 Véanse D. Eisenberg, Romances of chivalry in the Spanish Golden Age, pp. 119-129, y Fogelquist, El Amadís y el género de la historia fingida, J. Porrúa Turanzas, Madrid, 1982, pp. 122-124. 
virtió en uno de los juegos más finos de la ironía y de la complejidad narrativa de su Segunda parte del Quijote cuando ridiculiza al de Avellaneda (Prólogo al lector y caps. 59-60, 62, 70, 72 y 74$)$.

La reivindicación de Amadís de Gaula muestra la determinación de Silva de ubicar a su héroe como personaje principal en las crónicas de sus descendientes hasta la sexta generación, Rogel de Grecia. Aparte de admirar a Amadís, Silva, dedicado a complacer a sus lectores ${ }^{20}$ y a vivir, en parte, de la imprenta, calculaba tal vez que su héroe sería una atracción para los probables lectores de sus narraciones.

En consecuencia, Silva se sintió obligado a explicar en casi cada uno de sus libros, y con matices diversos, la capacidad de un caballero de sesenta, ochenta y hasta cien años para acometer aventuras como si fuera un mozo (en una ocasión el narrador declara simplemente que Amadís tiene ochenta años, pero que en su época la gente vivía hasta los trescientos, AGrecia I: 39). Silva heredó de Montalvo recursos útiles para preservar a sus héroes ancianos; uno es mantener a los personajes, tanto masculinos como femeninos, bajo los efectos de un encantamiento para que no envejezcan durante los años en que el futuro héroe recién nacido llega a los dieciséis (Lisuarte 34; Florisel I: 51 y II: 59); otro es el agua mágica de Urganda a la que Silva recurre en tres de sus libros (Lisuarte 34; AGrecia I: 51; y Florisel II: 23).

A mediados de Rogel I se resuelve la cuestión de la longevidad de Amadís y su familia de una vez por todas y de manera extravagante. Urganda y Alquife, ya muy viejos y cansados, pero en nada débiles en cuanto a sus poderes mágicos, producen otro baño extraordinario para conservar las fuerzas y belleza juveniles de los héroes y heroínas de las generaciones mayores. Más aún, fabrican un letuario o conservador de efectos maravillosos, cuya información Silva atribuye a Galersis, el ficticio cronista griego de los Rogeles, a Filastes Campaneo, el igualmente ficticio traductor del griego al latín. Por haber sido paganos, se les disculpan afirmaciones tan dudosas como éstas: "tenía esta conserva del fructo del árbol de vida que dios puso en el paraýso terrenal: la qual estos sabios pudieron aver por sus artes de que hizieron esta conserva que cient años de vida más de lo que

20 D. EISENBerg, Romances of chivalry in the Spanish Golden Age, pp. 75-85. 
avían de bivir les dieron"21. Los beneficiarios de estos tratamientos se conservan tan jóvenes y bellos como si tuvieran sólo treinta o cuarenta años, con la excepción graciosa de que los cabellos y las barbas de los varones se vuelven canosos (Florisel II: 23; Rogel I: 76). La transferencia de responsabilidad en cuanto a la verdad de ciertos informes sería útil más de una vez a Cide Hamete (II: 5 y 24, por ejemplo).

Con sus dotes juveniles no extraña que los héroes amadisiacos acometan tantas y tan diversas aventuras. Una y otra vez Amadís de Gaula destaca en múltiples episodios o situaciones. Algunos son de alcance muy amplio, como la defensa de Trapisonda o de Constantinopla contra invasiones de sus enemigos o miembros de su familia, hechos tan importantes en los libros de Silva como en los tres últimos libros del Amadís de Montalvo y en las Sergas de Esplandián (Lisuarte 20-42; Florisel II: 13-30; Rogel II.1: 64-67 y 81-87) ${ }^{22}$. Amadís tiene el papel central en varias de estas batallas campales. Es él quien suele pronunciar la arenga principal y formular los planes estratégicos para el ejército defensor. Luego entra en lo más reñido del conflicto armado a la cabeza de un batallón. Estos encuentros dan lugar a combates singulares entre un número reducido de los héroes más preciados de los dos bandos para decidir la victoria sin excesiva pérdida de sangre. Amadís siempre es uno de los campeones elegidos.

En los libros de Silva, y desde la derrota a manos de su padre, la figura de Esplandián pasa a segundo plano ${ }^{23}$; figura en la defensa de Constantinopla, sin destacar mucho, aunque es

${ }^{21}$ Rogel I: 95; SAlEs Dasí comenta el episodio en "Las Sergas de Esplandián y las continuaciones del Amadís (Florisandos y Rogeles)", p. 156.

22 Varios críticos han comentado recientemente el tema de Constantinopla y las batallas campales que por ella se hacen en los tres últimos libros del Amadis de Montalvo: Avalle-Arce, op. cit., pp. 244-245 y 263-270; en las Sergas: J. FogelQuist, op. cit., pp. 180-186; en varios libros de caballerías: Luciana Stegagno Picchio, "Fortuna iberica di un topos letterario: La corte di Costantinopoli dal Cligès al Palmerín de Olivia", Studi sul Palmerín de Olivia, Universitá, Pisa, 1966, pp. 99-136 y Rafael Ramos Nogales, "El Amadís y los nuevos libros de caballerías 1495-1530”, Íns, 1995, núms. 584/585, 23-25. Sobre este tema en los libros de Silva véanse los comentarios de M. C. DANIELS, art. cit., pp. 83-85, y SALES DASí, "Las Sergas de Esplandián y las continuaciones del Amadís (Florisandos y Rogeles)", pp. 150-151 y "Feliciano de Silva y la tradición amadisiana en el Lisuarte de Grecia", pp. 7 y 13-23.

23 Sales Dasí, "Feliciano de Silva y la tradición amadisiana en el Lisuarte de Grecia", p. 17. 
emperador de la ciudad. En uno de los sitios queda herido de gravedad y Florestán, a quien el narrador de las Sergas había admirado más que a Amadís de Gaula, muere luchando contra los sitiadores (Florisel II: 28).

Los combates singulares de Amadís se describen con lujo de detalles; así, por ejemplo, los combatientes de ambos ejércitos se detienen admirados a observar su pelea contra el gigante Grisilante (Lisuarte 42). Pero, aun más elaborado es el episodio en que, durante otro sitio de Constantinopla, el rey Macartes desafía a Amadís a un combate singular con el fin de acrecentar, gane o pierda, su honra. Para llevar a cabo el desafío interrumpen la batalla por varios días. Los preparativos son elaboradísimos, y el duelo se efectúa entre mucho boato y con discursos y réplicas corteses e ingeniosos, tratamiento que sigue recibiendo Macartes cuando queda vencido (Florisel II: 24).

Amadís emprende una buena cantidad de demandas caballerescas solitarias, o en compañía de una sola persona. Estas demandas se encuentran en todos los libros de Silva y recorren la gama de aventuras típicas de los libros de caballerías. En una de ellas Amadís mata al gigante Mascarón que ha usurpado el reino de la princesa Malfadea después de violarla y asesinar a sus padres (AGrecia I: 39-40). Este episodio reúne varios de los mismos motivos que el de Dorotea/Micomicona en el Quijote (I: 29-30); en otra demanda de este tipo Amadís defiende y exonera a la reina Buruca que ha sido falsamente acusada de adulterio (AGrecia I: 50-51). También emprende Amadís las aventuras arquetípicas de socorrer a damas menesterosas secuestradas por piratas o por malos caballeros (AGrecia II: 25-26 y 56; Florisel II: 56; Rogel II.2: 79 y 82-84). En una ocasión los gigantes Monstruón y su hermano llevan forzadas a Oriana, Briolanja y Lucenda. Amadís de Gaula, Galaor y Amadís de Grecia persiguen al grupo, matan a los gigantes y liberan a sus amadas (AGrecia II: 25-26). Varios elementos de este episodio coinciden con los intentos de don Quijote por "rescatar" a la señora vizcaína (I: 8 y 10 ).

Pocas veces se encuentra Oriana en peligro en los libros de Silva, pero, a su manera, comparte la reivindicación de su esposo Amadís. Su papel es menos elaborado, pero no carece de matices e importancia. Acompaña a su marido a muchas partes, como en los viajes oficiales a Trapisonda y Constantinopla, pero no en las demandas peligrosas. En ocasiones demuestra su desacuerdo con la presteza de su marido a exponerse a tan- 
tos riesgos. Durante una de las ausencias de su esposo, Oriana se viste de negro para manifestar su ansiosa inseguridad (AGrecia I: 47). Lamenta otra ausencia de Amadís con estas expresiones sentidas:

Ay santa maría a qual gran coraçón del rey quanta enemistad tiene comigo y con el que en tantas afrentas nos pone: paréceme a mí que ya era tiempo de dexarnos descansar \& no poner su persona y estado en tanta afrenta teniendo en su casa tantos buenos cavalleros que le podían quitar destos cuydados (AGrecia I: 39; otra queja suya parecida en Florisel II: 21).

Ese tono dolido de Oriana es el de las mujeres de todas las clases sociales cuyos hombres han partido a la guerra (así también son las quejas de la sobrina y del ama de don Quijote, II: 6-7 y 73).

No obstante las tensiones y el paso de generaciones, el amor entre Oriana y Amadís no disminuye. Acaso contribuyen a esto los recursos mágicos de Urganda y Alquife, que conservan fresca su belleza perpetua, pero no tanto como su fidelidad en el amor, que contrasta con la mayoría de sus descendientes masculinos que tienen amores diversos $\mathrm{y}$, con pocas excepciones, sin remordimientos ${ }^{24}$. Este amor legendario, en las numerosas pruebas de lealtad, entre Amadís y Oriana da lugar a una clase de aventura caballeresca en la que esta pareja sobresale como ninguna otra.

En algunas aventuras de encantamiento, las figuras de Amadís u Oriana ocupan el puesto central del recinto privilegiado. La figura o imagen puede ser o parecer una estatua (Florisel I: 26) o actuar como deus ex machina, señalar y premiar a las personas que triunfan en la aventura (Florisel I: 7; Rogel I: 49). En las ocasiones en que Amadís y Oriana prueban en persona aventuras de esta especie, sólo ellos alcanzan el mayor grado de triunfo (AGrecia II: 71; Rogel II.1: 47). Esplandián y Leonorina también triunfan en pruebas de lealtad amorosa, pero - y aquí se confirma la determinación de Silva por favorecer a su pareja destacada- la narración es parca.

Amadís y Oriana protagonizan desencantamientos espectaculares que culminan en dos secuencias de máxima importancia en sus libros respectivos ${ }^{25}$. En AGrecia, Amadís de Gaula y Oriana dan

24 Véase esp. M. C. Daniels, op. cit., cap. 6.

25 D. EISENBERG, Romances of chivalry in the Spanish Golden Age, p. 82. 
remate al encantamiento llamado la Gloria de Niquea, la aventura de este tipo más importante del libro. Sólo deben probarla los que han sido fieles a una sola persona, porque los otros serán incinerados si intentan entrar a la torre o castillo. Este obstáculo ha frustrado, entre otros, a Amadís de Grecia, héroe del libro y el más interesado en desencantar a su amada princesa. Pero Oriana avanza al estrado donde está la hermosa Niquea encantada sin la menor dificultad (AGrecia II: 79). Amadís también llega a esta cámara donde acomete al gigante Montón de la Liza y le corta la cabeza que choca con el espejo situado frente a Niquea, el espejo se quiebra y se deshace el encantamiento (AGrecia II: 82). También el Quijote cree haber descabezado al gigante cuando ataca los cueros de vino en la venta (I: 35). Ocurre lo mismo con el final del episodio de Clavileño, en el palacio de los Duques, con que se pone fin al encantamiento de Trifaldín y la Dueña Dolorida en el Quijote (II: 41) que coincide en muchos detalles con un episodio de Rogel I; Amadís y Oriana apenas entran en la famosa Torre de Diana cuando el encantamiento se deshace en un espectáculo pirotécnico (cap. 154).

A la fidelidad, tantas veces confirmada, de su esposo responde Oriana con seguridad. Ya no siente celos, como en el segundo libro de Amadís de Gaula, y acepta que él preste servicios honestos y trate con cortesía a las damas. Esta confianza da lugar a una situación inusitada para ambos: la duquesa Cleófila se ha enamorado de él por la fama de sus proezas, por su aspecto aún juvenil, y hasta por la dignidad que le dan su barba y cabello canos. Cleófila declara en público un amor honesto y puro, a cambio del cual sólo espera una recompensa también honesta y pura de Amadís. Tanta es la sinceridad y cortesía de Cleófila que Amadís accede con expresiones parecidas, y Oriana acepta benevolente, confiada en la fidelidad de su esposo (Florisel II: 23 y 25) ${ }^{26}$. Así se entabla una relación afectuosa entre Cleófila y Amadís que da lugar a unas aventuras en las que él la rescata de situaciones peligrosas (Florisel II: 32; Rogel I: 103-04). Al cabo Cleófila pide emparentarse con Amadís, quien dispone su boda con un príncipe de su linaje, Arlanges de España (Rogel I: 145).

${ }^{26} \mathrm{El}$ intercambio de finezas incluye un juego paronomástico de veinticuatro líneas rellenas de cinco instancias del vocablo gloria y derivados, y doce instancias de merecery derivados. Se parece mucho al segundo ejemplo de los excesos estilísticos de Silva que Cervantes parodia al principio del Quijote $(\mathrm{I}, 1)$ en donde divino y merecer son las raíces del juego. 
Amadís de Gaula es uno de los héroes que más participa en lo que es tal vez el aspecto más singular de los libros de Silva: la presencia destacada de amazonas y mujeres guerreras ${ }^{27}$. Calafia, la reina amazona de California, que fue su enemiga en las Sergas de Montalvo, en el Lisuarte de Grecia de Silva pelea al lado de Amadís: él, contra el gigante Grisilante, ella, contra la reina Pintiquinestra. Amadís vence a Grisilante y lo mata cuando se niega a convertirse a la verdadera fe. Calafia vence a Pintiquinestra, pero ésta ofrece hacerse cristiana a cambio de la promesa de Amadís de casarla con uno de la familia de él (cap. 42) ${ }^{28}$. Poco después Amadís presta a Pintiquinestra su famosa Verde Espada con la que esta amazona parte al gigante Almirix de la cabeza hasta la cintura (Lisuarte 45). En un incidente parecido, Amadís presta su espada a otra reina amazona, Xarandria, con la que vence al rey gigante Sardapión (Rogel II.1: 63bis-64bis) .

El personaje femenino con quien más afecto comparte Amadís de Gaula es la virgo bellatrix Alastraxerea, hija de Amadís de Grecia y de la reina amazona Zahara. Amadís de Gaula y Alastraxerea se encuentran por primera vez, sin sospechar el parentesco, como enemigos en el campo de batalla. Se estiman tanto por la fama que ambos gozan que se niegan a combatir una contra otro y se protegen mutuamente, deteniéndose en momentos para intercambiar expresiones de admiración y respeto (Florisel II: 15). Con orgullo especial Amadís descubre que ella

${ }^{27}$ Estos personajes femeninos han recibido amplia atención de la crítica. Consúltense los estudios de TAufer, "From amazon queen to female knight: The development of the woman warrior in the Amadis cycle", caps. 5 y 6 , y "The only good amazon is a converted amazon: The woman warrior and christianity in the Amadís cycle", pp. 35-51; María Carmen Marín Pina, "Aproximación al tema de la virgo bellatrix en los libros de caballerías españoles”, Criticón, 1989, núm. 45, 81-94; y M. C. DANIELs, op. cit., pp. 207-210, para análisis e información bibliográfica. Estas investigadoras hacen clara la distinción entre amazona (Calafia, Pintiquinestra, Zahara, Xarandria) y mujer guerrera (Alastraxerea).

${ }^{28}$ M. C. DANiELS, art. cit., pp. 83-85; TAufER, "The only good amazon is a converted amazon: The woman warrior and christianity in the Amadis cycle", pp. 35-51; y SALes DAsí, "Las Sergas de Esplandián y las continuaciones del Amadís (Florisandos y Rogeles)", pp. 150-151, comentan el tema de la relación entre los caballeros cristianos del linaje de Amadís y los "paganos", y la conversión de éstos a la fe cristiana en los libros de Silva. Whitenack analiza este fenómeno en otros libros de caballerías: "Conversion to christianity in the Spanish romance of chivalry, 1490-1524", y "Don Quixote and the romances of chivalry once again: Converted Paganos and enamoured Magas", Cervantes, 13 (1993), 61-91. 
es su tataranieta (Florisel II: 55-56). Alastraxerea es uno de los personajes más destacados del Florisel y de los Rogeles, y Amadís de Gaula la tiene de compañera de armas en otras batallas campales, combates de desafío y demandas (Florisel I: 68 y II: 56-58; Rogel II.1: 147-50 y II.2: 79).

Aparte de los episodios en que Amadís figura como personaje activo de primera magnitud, hay muchos en que otros personajes o el narrador realzan su importancia cuando recuerdan sus hazañas de juventud o lo mencionan con reverencia como un modelo incomparable de caballero y amante leal (Florisel II: 103, por ejemplo) ${ }^{29}$. Conmemoran en ocasiones sus aventuras más famosas, como su victoria sobre el endriago (Rogel II.1: 46), o el Arco de los Leales Amadores (Rogel I: 49) o los celos de Oriana y la penitencia de Beltenebros (Rogel II.1: 41 y Rogel II.2: 82). Este es el tema de un romance cantado por el príncipe Agesilao cuando está disfrazado de doncella, llamándose Darayda (Rogel I: 19).

En los libros de Silva se encuentran representaciones visuales de momentos sobresalientes de la historia de Amadís y de Oriana, como los tapices que adornan un gran salón de un palacio encantado (Lisuarte 69) y en las imágenes o efigies de las vitrinas del fabuloso palacio del Alto Roquedo fabricado por la maga Zirfea (Rogel I: 88). Al probar la Aventura de la Selva, Oriana ve pasar en una esfera mágica la historia de su vida y de Amadís representada por figuras animadas (Rogel II.2: 97). Florisel, el tataranieto de ambos, presencia varias de aquellas experiencias representadas como en vivo en la Aventura del Espejo de Amor (Florisel I: 7).

No todo lo relacionado con Amadís de Gaula en los libros de Silva es bélico o erótico. Amadís cumple muchas funciones tranquilas típicas de un monarca venerado, como en los últimos libros del Amadís de Montalvo ${ }^{30}$. Una de estas funciones es conferir la orden de caballería a los donceles que se lo piden como premio (Lisuarte 46, 48 y 69; AGrecia I: 21; Rogel II.1: 21). Él y Oriana apadrinan bodas y conversiones a la fe cristiana (Lisuarte 42 y 78; AGrecia I: 49; Rogel II.2: 73). También presiden justas o combates singulares (Lisuarte 65-76; AGrecia I: 20-23 y 46-47).

En el mismo ámbito cortesano Amadís y Oriana suelen recibir trofeos enviados por deudos y admiradores. En una ocasión, aca-

${ }^{29}$ La mayoría de los tipos de conmemoraciones resumidos aquí habían figurado ya en el Amadís de Gaula y en las Sergas de Esplandián de Montalvo, como ha observado FogelQuist (op. cit., pp. 56-60 y 72). Véase infra, nota 32.

${ }^{30}$ J. B. Avalle-Arce, op. cit., pp. 309-311. 
bando de cenar Oriana con su séquito, una doncella le entrega la cabeza del gigante Gadalfe que manda el Caballero de la Ardiente Espada (pseudónimo de Amadís de Grecia; AGrecia I: 48), quien se complace en hacer regalos peculiares a sus famosos bisabuelos; el más espantoso, que también llega como postre, es la piel de la horripilante bestia Serpentaria (AGrecia II: 48). Estos son trofeos harto aparatosos, pero el tributo más sentido que el Caballero de la Ardiente Espada ha brindado a Amadís de Gaula es haber adoptado el nombre Amadís de Grecia (AGrecia I: 66), sin saber que es el bisnieto de su héroe y que este nombre se lo había dado su madre antes de que unos corsarios lo robaran recién nacido y lo llevaran a la India (Lisuarte 100).

El prestigio que inspira tantos tributos combinado con su prudencia de monarca maduro conducen a otro ministerio importante de Amadís: el de juez o mediador. Esta función parece corresponder a los consejos dados por la sabia Urganda en su carta al final de Amadís de Gaula citada arriba. Con mediaciones razonables y serenas Amadís de Gaula persuade al Caballero de la Ardiente Espada que Brimartes no ha sido su rival para el amor de la princesa Lucela y logra convertir una enemistad prolongada y violenta en amistad (AGrecia II: 21). Poco después Amadís de Gaula convence, mediante argumentos acompañados de una amenaza, a una duquesa sexualmente incontinente a desistir de su práctica inusitada de tomar preso a todo caballero que pasa por su castillo, forzándole a hacer el amor a cambio de no ser quemado vivo (los dos Amadises apenas llegan a tiempo de salvar a uno que estaba a punto de ser carbonizado; AGrecia II: 21).

Los mismos dos paladines sirven como jueces formales para fallar sobre un caso de enredo amoroso al estilo de los que estaban muy al gusto de la narrativa de la época. Dos príncipes hermanos aman a dos princesas hermanas, pero cada una de éstas, en vez de corresponder con su amor al príncipe que la ama, quiere al que ama a su hermana. Los dos padres, para resolver este conflicto y las guerras constantes entre ellos, se han puesto de acuerdo para obligar a cada princesa a elegir al príncipe con quien se quiere casar y a justificar su elección en el tribunal presidido por los Amadises. La princesa que gane y su nuevo marido heredarán los dos reinos; los que pierdan pasarán el resto de su vida presos en una torre. Las princesas eligen al mismo príncipe, una porque lo ama, la otra porque es amada por él. Ellas sacan a relucir un considerable talento persuasivo con sus argumentos. Después de dos días de deliberaciones los 
Amadises fallan en favor de la que no ama, pero también piden llevar a los perdedores a otro reino que Amadís de Gaula posee y que quiere donarles para que no tengan que sufrir la cadena perpetua. Tan bien sale el asunto que a poco tiempo nace en cada uno de los recién casados un amor para su pareja tan fuerte que todos se olvidan de su primera pasión (Rogel I: 146-149).

La cantidad e importancia de las acciones en que corresponde a Amadís de Gaula el papel principal atestiguan el honroso lugar que Silva le dio en sus libros. Más aún, casi todas las hazañas notables de Amadís tienen lugar en los momentos más dramáticos de las largas secuencias narrativas. Así lo compuso Silva para terminar el segundo libro de la segunda parte de Rogel de Grecia, en el que, al parecer, quiso volcar su imaginación para recalcar una vez más el valor especial de Amadís y de once de sus héroes predilectos. Los doce escogidos emprenden por caminos distintos la demanda de rescatar a la princesa Gradafilea, la virgo bellatrix que a lo largo de estas crónicas ha sido la fiel amiga desinteresada de Lisuarte de Grecia (Rogel II.2: 79). Lisuarte y otros tres logran liberar a Gradafilea de sus captores. Luego éstos y otros siete de los héroes acaban aventuras que parecen clausurar o coronar sus largas e ilustres carreras. Silva no dejó cabos sueltos en las trayectorias de estos diez, y ni siquiera involucró en esta demanda a los héroes principales de la última generación, Rogel de Grecia y el segundo Agesilao, porque acaban de celebrar sus bodas, lo que suspende el curso de sus andanzas. Los que se destacan en esta coyuntura son Amadís de Gaula y Esplandián, porque están destinados a resolver enredos cuyos desenlaces apuntan a otra continuación de la serie; el hijo vuelve por primera vez al primer plano en los libros de Silva después del combate singular con su padre en Amadís de Grecia.

Las experiencias de Amadís y de Esplandián en esta demanda son paradigmáticas de recursos temáticos y discursivos de Silva que van en aumento en Rogel I y II: casos amorosos anómalos, escenarios de interiores de palacios o de jardines, oratoria florida, diálogo extenso y humor burlesco ${ }^{31}$. Bien se echa de ver en esto que Silva, como autor que era de Segunda Celestina (1535), ya se inclinaba tanto a lo teatral como a lo narrativo ${ }^{32}$.

31 S. P. Cravens, op. cit., caps. 3 y 4; M. C. Daniels, op. cit., passim; y Sales DAsí, "Las Sergas de Esplandián y las continuaciones del Amadís (Florisandos y Rogeles)”, pp. 147-156.

32 En 1940 George I. Dale comentó brevemente la tendencia en los li- 
En su viaje Amadís llega al castillo de una dama dolorida, Esmerilda, abandonada por su amado Golisel del Monte Gris por celos mal fundados. Amadís la consuela durante dos entrevistas prolongadas, contándole de los celos de Oriana y de su penitencia como Beltenebros (todo en tercera persona para ocultar su identidad). Promete buscar al ausente Golisel para desengañarlo ( $R o-$ gel II.2: 82-84). Estas escenas están cargadas de sentimentalismo lacrimoso, matizado burlescamente por el aparte de dos doncellas que se mofan de los discursos aburridos y largos de Amadís. Situación parecida a la de don Quijote con doña Rodríguez mientras la duquesa y Altisidora escuchan escondidas (Quijote II, 48 y 50). Las que escuchan a Amadís y Esmerilda debaten desvergonzadamente sobre la posibilidad de que Amadís, a pesar de sus canas, pudiera ser un buen amante para mozas como ellas. Luego cuando las jóvenes conducen al venerable héroe a la recámara donde debe pasar la noche, una sugiere socarronamente mandar a otra "doncella" a acostarse con él, lo que él rechaza con la seriedad posible, aunque reconoce el intento humorístico de la oferta. El comportamiento de las "doncellas" con Amadís tiene mucho en común con el de Altisidora durante el acoso burlesco al caballero manchego (Quijote II: 46 y 57 ).

Como si la subversión celestinesca de las dos cuasi doncellas no fuera suficiente, la aventura de Amadís se complica con otro enredo aun más escandaloso: la hermana de Esmerilda, Andreda, acude llorosa contando que su marido la ha sacado del castillo para quedarse él allí con una amante. Indignado, Amadís parte para castigar a los adúlteros pero, antes de poder corregir al marido infiel, encuentra a su hermano Galaor, el perenne seductor, acostado con otra de las "doncellas" que abundan en este episodio. Entre enfadado y sonriente Amadís regaña a su hermano. El humor que domina la narración hace sospechar de la promesa de

bros de Silva a lo ceremonial, lo lúdico y lo teatral. Para otros comentarios al tema, Cravens, op. cit., pp. 45-46 y 75-80; M. C. Daniels, op. cit., caps. 1 y 6-7, y passim; y SAles Dasí, "Las Sergas de Esplandián y las continuaciones del Amadís (Florisandos y Rogeles)", pp. 154-156 y "Feliciano de Silva y la tradición amadisiana en el Lisuarte de Grecia", Incipit, 18 (1998), pp. 18 y 36-37. RAFAEL Beltrán ha recalcado este aspecto de Tirant lo Blanch en "Las bodas sordas en el Tiranty la Celestina", RFE, 70 (1990), 90-117, passim; Giuseppe Grilli, "Tirant lo Blanc e la teatralità", Actes del Symposion Tirant lo Blanc, Quaderns Crema, Barcelona, 1993, passim; y RAFael Mérida, "La desaparición de Morgana: de Tirant lo Blanc (1490) y Amadís de Gaula (1508) a Tyrant le Blanch (1737)", $B A B L, 46$ (1998), p. 139. 
Galaor de reformarse (Rogel II.2: 84). Es curioso, por lo menos, que Silva, después de tanta insistencia en reivindicar a Amadís, lo haya hecho participar al final de su último libro en situaciones tan escabrosas en cuanto al contenido moral ${ }^{33}$. Por otra parte, este episodio permite a Amadís demostrar una vez más su entereza legendaria en medio de la desenvoltura de otros personajes, como también hace don Quijote en la mayoría de los casos semejantes, por lo menos en la Segunda parte.

Esplandián, ignorante de lo sucedido con su padre y su tío, sigue la demanda por su ruta y llega a otro castillo donde encuentra al mencionado Golisel del Monte Gris comprometido ahora como testigo y consejero en el enredo amoroso de dos hermanos y una prima. Uno de los hermanos, enfurecido por los celos, ha encerrado al otro y a la prima en sendas jaulas, donde los consuelan Golisel y Esplandián, quien, moralista como de costumbre, sermonea sobre el caso y ordena a todos que en treinta días se reúnan en Constantinopla para determinar allí la solución al conflicto (Rogel II.2, 91-94).

Por lo visto, el plan de Silva era reservar únicamente para Amadís y Esplandián la oportunidad de resolver los dos casos reunidos en un libro posterior. Desafortunadamente los dos héroes nunca pudieron llevar a cabo la empresa, porque su fiel cronista murió en 1552, un año después de la publicación de este último libro suyo. Algunos decenios después, otro escritor tendría en preparación un libro sobre otro caballero envejecido en el que las características subversivas que Feliciano de Silva elaboró en la última demanda del anciano Amadís alcanzarían una esfera artística incomparable e inmortal: el Quijote de $1605^{34}$.

Sydney Paul Cravens

Texas Tech University

33 Como varios héroes de su familia, Amadís había sido víctima de las burlas del Fraudador de las Ardides (Rogel I: 150 y 151). M. C. Daniels ha analizado en detalle estos episodios (op. cit., pp. 253-260) como parte de un capítulo dedicado a este caballero burlesco que casi seguramente captó la atención de Cervantes. Véase también a Sales Dasí, "Las Sergas de Esplandián y las continuaciones del Amadís (Florisandos y Rogeles)", pp. 151-152.

${ }^{34}$ Hago constar mi sincero agradecimiento a Rafael M. Mérida Jiménez por haberme encaminado a unos estudios recientes sobre los libros de Silva, a Emilio J. Sales Dasí por la misma causa y por haberme enviado una copia mecanografiada de un artículo suyo, y a Daniel Eisenberg por haberme proporcionado, como en ocasiones anteriores, información y consejos valiosos. 